\title{
Sex ratio, gonadal and condition indexes of the Asiatic hard clam, Meretrix meretrix in Marudu Bay, Malaysia
}

\author{
LADITAH DUISAN ${ }^{1}$, GAZALI SALIM ${ }^{2}$, JULIAN RANSANGAN ${ }^{1, v}$ \\ ${ }^{1}$ Borneo Marine Research Institute, Universiti Malaysia Sabah. Sabah Port Bypass, 88400 Kinabalu, Sabah, Malaysia \\ ${ }^{2}$ Department of Aquatic Resource Management, Faculty of Fisheries and Marine Science, Universitas Borneo Tarakan. Jl. Amal Lama No. 1, Tarakan, \\ North Kalimantan, Indonesia.`email: liandra@ums.edu.my \\ Manuscript received: 20 August 2021. Revision accepted: 20 October 2021.
}

\begin{abstract}
Duisan L, Salim G, Ransangan J. 2021. Sex ratio, Gonadal and Condition indexes of the Asiatic Hard Clam, Meretrix meretrix in Marudu Bay, Malaysia. Biodiversitas 22: 4895-4904. Asiatic hard clam, Meretrix meretrix is one of the important shellfishery resources in Marudu Bay, Sabah, Malaysia. It is among the most popular clam species being widely traded in the local wet markets around Sabah, Malaysia. Unfortunately, the shellfishery management for this species has not been well established. In addition to overexploitation, habitat destruction is also one of the significant threats to this species due to the extensive land use of the coastal areas in Sabah. Hence, conservation and breeding efforts for this species are greatly required. Therefore, the current study was conducted to examine the sexual maturity of the clam with respect to shell length classes for artificial seed production purposes. For this study, a total of 86 clam specimens were randomly collected from mudflats in Marudu Bay. The specimens were utilized for gonad histological and condition analyses. The clams were grouped into three shell length classes; (3.00-4.99) cm, (5.00-6.99) cm, and (7.00$8.99) \mathrm{cm}$ prior to the analyses. Results showed the natural stock of the Asiatic hard clams in Marudu Bay was dominated by females (1.39:1) over males with no hermaphroditism observed. The gonadal index was recorded higher among clams with shell lengths between 5.00 and $6.99 \mathrm{~cm}$. The condition index analysis also recorded high $(>4.0)$ for clams in all the shell length classes. The findings of this study suggest that the clams with shell lengths between $5.00 \mathrm{~cm}$ and $7.00 \mathrm{~cm}$ are already fully matured and can be utilized as a broodstock candidate for an artificial breeding program in the hatchery.
\end{abstract}

Keywords: Aquaculture, maturity, Veneridae, venus clam

\section{INTRODUCTION}

Shellfish is an important source of livelihood in coastal communities worldwide (Oliveira et al. 2013; Rohmah and Muhsoni 2020). Generally, it is affordable (Lagade et al. 2013) and contains similar amounts of protein, glycogen, and minerals as other kinds of seafood (Sundaram and Deshmukh 2011; Jaya et al. 2017). Marudu Bay, Sabah, Malaysia is surrounded by pristine mangrove forest which provides suitable habitats for breeding and nurseries of both fishes and shellfishes (Zakaria and Rajpar 2015; Mojiol et al. 2016). Furthermore, one of its important shellfishery resources is the Asiatic hard clam (Meretrix meretrix) which inhabits the intertidal zones and supports artisanal fishery (Hamdan et al. 2019). However, recent studies showed that this species is overexploited (Tan et al. 2017; Admodisastro et al. 2021). Despite the significant economic contribution, little is known about the sexual maturity of this clam that creates challenges for the fishery management, conservation, and stock restoration of this species.

Knowledge about the sex ratio is important for fishery management and the conservation of economically important bivalve species because it provides information about the proportion of males and females in a population (Adebiyi 2013; Martínez et al. 2014). Furthermore, it is used to verify the capability of the bivalve concerned in undergoing sex reversal (Guo et al. 1998). Finally, such knowledge helps select the right proportion of male and female brood-stocks in an artificial breeding program.

The gonadal analysis (e.g., gonadal index) has been used to determine the gonad maturation in bivalves. Unfortunately, the determination of sex via histological examination usually requires the sacrifice of clam (ChávezVillalba et al. 2011; Sawant 2012; El-Deeb et al. 2018). Furthermore, this analysis enables an accurate forecast of timing for the spawning season (Hamli et al. 2015), thereby significantly improving resource management for bivalve fisheries. These data are also exploited in the selection of bivalve brood-stock for the artificial breeding program. Similarly, the condition index does not only verify the maturation phases of the gonad (Acarli et al. 2018) but also serves as an indicator of the overall health status of a bivalve, and it is often utilized in the verification of meat quality, as well as to predict the harvest time for farmed bivalves (Acarli et al. 2018). Hence, this study aims to determine the sex ratio, gonadal and condition indexes of the natural stock of the Asiatic hard clam, Meretrix meretrix in Marudu Bay in view of the need to conserve and restore the stock of this species through aquaculture activities in the future. 


\section{MATERIALS AND METHODS}

\section{Sample collection}

Specimens of Asiatic hard clam, Meretrix meretrix were collected at the four mudflats (A, B, C and D) within the inner part of the Marudu Bay, Sabah, Malaysia (Figure 1). These sites were selected because they are the common fishing grounds for hard clam in the bay. The clams were collected using the traditional fishing gear locally called "kerek" or hand dredging tool following the technique described by Tan and Ransangan (2019). A total of 86 live clam specimens with different shell length sizes were successfully collected between May 2017 to April 2018. In every sampling trip, clam specimens were kept moist in Styrofoam boxes and transported to the Borneo Marine Research Institute, Universiti Malaysia Sabah, for laboratory analyses.

\section{Condition index}

At the laboratory, clam specimens were cleaned and dissected. Then, the meats and shells were separated and dried in a drying oven at $60^{\circ} \mathrm{C}$ until a constant weight was achieved. The condition index (CI) was then calculated following Walne (1976) as follow:

$$
C I=\frac{\text { Dry Meat Weight }}{\text { Dry Shell Weight }} \times 100
$$

\section{Gonad histological examination}

Gonad development stages ((i) inactive or resting, (ii) early gametogenesis, (iii) advanced gametogenesis, (iv) mature, and (v) spawned) and the sex ratio was determined by the examination of the histological slides of gonad tissues. The histological examination of gonad tissues followed the methods described by Yurimoto et al. (2008) and Acarli et al. (2018). Briefly, each clam specimen was dissected to obtain the gonad. The gonad samples were then fixed in Bouin solution for 24 hours and dehydrated in a series of alcohol solutions ( $70 \%$ to $100 \%$ ), cleared in two dips of $100 \%$ xylene and then embedded in paraffin. The paraffinized gonad tissues were mounted on wooden blocks and sectioned by the Shandon Microtome (Thermo Scientific, USA) into $7 \mu \mathrm{m}$ thick and stained with hematoxylin-eosin staining following Howard et al. (2004). The slides were then observed under a light microscope (Leica, Germany) at 10X magnification to determine the gender and the gonad developmental stages following the criteria suggested by da Silva et al. (2009).

\section{Gonad index}

The gonad development stages observed under a microscope were ranked into 4 categories following Buchanan (2001) and Wilson and Seed (1974), as given in Table 1.

Finally, the gonadal index (GI) was then calculated according to the formula suggested by King et al. (1989) as follows:

$$
G I=\frac{\Sigma \mathrm{nR}}{N}
$$

Where, $n$ denotes number of each stage; $N$ denotes total sample size and $R$ denotes rank of stage.

\section{Statistical analyses}

The significant difference of sex ratio among clams with different shell length classes was analyzed using the weighted chi-square analysis. As for condition and gonadal indexes, Kruskal-Wallis test (IMB SPSS Statistics 26) was employed. All analyses were tested at 95\% confidence level. Prior to analysis of the condition and gonadal indexes, data were first tested for normality using the Shapiro-Wilk test (IBM SPSS Statistics 26). Tests were considered significant when the p-value was less than 0.05 .

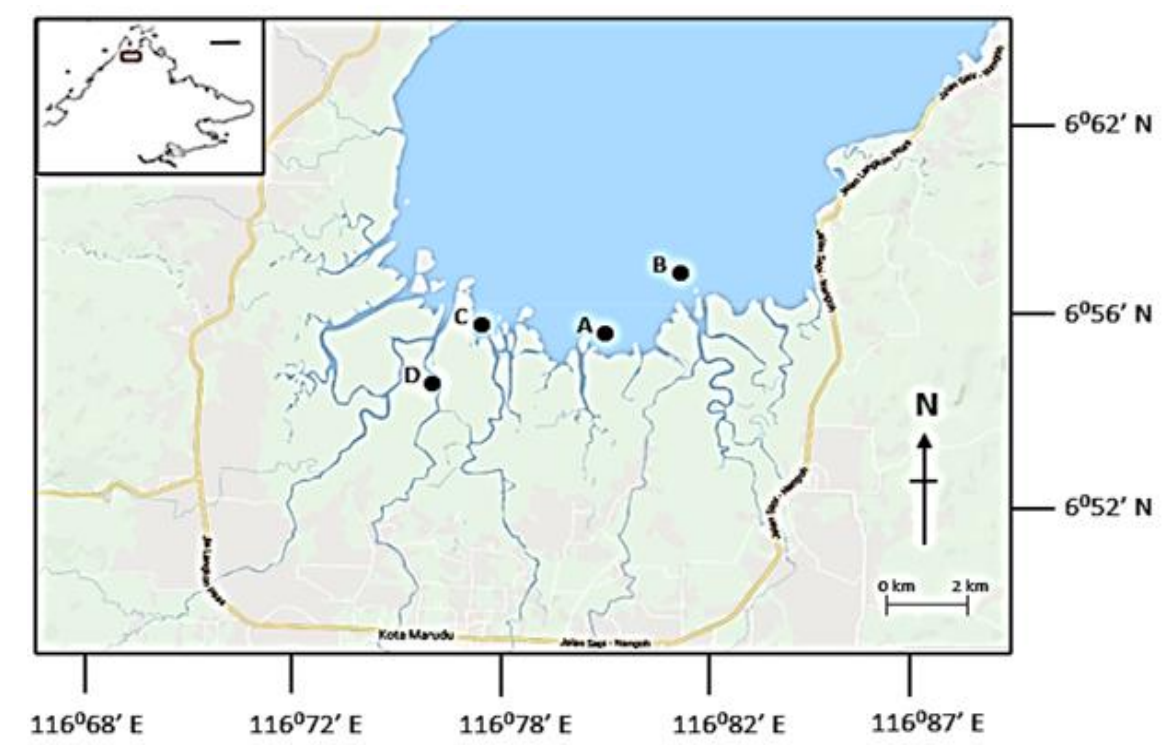

Figure 1. Sampling sites (A, B, C and D) of the Asiatic hard clam, Meretrix meretrix in Marudu Bay, Sabah, Malaysia 
Table 1. Description and the numerical scoring given to each of the gonad developmental stages

\begin{tabular}{|c|c|c|c|}
\hline & Stage & Score & General description \\
\hline 0 & Resting & 0 & $\begin{array}{l}\text { Animal has completed spawning. Gonad is mostly comprised of storage cells. Sex determination } \\
\text { cannot be done. }\end{array}$ \\
\hline 1 & Immature & 1 & $\begin{array}{l}\text { Gametogenesis has started, follicles visible but no mature gametes apparent. Small clusters of } \\
\text { germinal cells are scattered throughout the connective tissue. Oogonia and spermatogonia fanned from } \\
\text { the germinal epithelium line the walls of the follicles. Sex determination is still difficult, especially in } \\
\text { the early phases of this stage. }\end{array}$ \\
\hline 2 & Developing & 2 & $\begin{array}{l}\text { The follicles in both males and females occupy a large part of the mantle. In males, masses of primary } \\
\text { and secondary spermatocytes and spermatids fill the follicles while small darkly staining nuclei of } \\
\text { spermatozoa are scattered among the larger cells. In females, oocytes have begun to accumulate yolk } \\
\text { and have grown considerably. Some of the larger oocytes are still attached to the follicular epithelium } \\
\text { by a slender stalk of cytoplasm which eventually ruptures to leave the oocyte free within the follicle. }\end{array}$ \\
\hline $3 \mathrm{~A}$ & Ripe & 3 & $\begin{array}{l}\text { The gametes are now morphologically ripe. In males, the follicles are packed with spermatozoa } \\
\text { arranged in lamellae converging towards the center of the lumen. A few residual spermatocytes and } \\
\text { spermatids may still be present. In females, majority of the oocytes have reached their maximum size } \\
\text { and are packed tightly together in the follicles. The pressure within these follicles compresses the } \\
\text { oocytes into polyhedral forms. The connective tissue has lost most of its reserves of glycogen and } \\
\text { lipid, which may be almost completely obscured by the swollen follicles. }\end{array}$ \\
\hline $3 \mathrm{~B}$ & Spawning & 2 & $\begin{array}{l}\text { Gametes have begun to be released. Large numbers of ripening oocytes are still present in the } \\
\text { follicles. Residual oocytes tend to be spherical as the reduction in numbers greatly reduces } \\
\text { compaction. Large numbers of spermatozoa line the follicles. }\end{array}$ \\
\hline $3 \mathrm{C}$ & Redeveloping & 3 & $\begin{array}{l}\text { Rapid proliferation and growth of oocytes and a densely staining band of spermatids has given rise to } \\
\text { new lamellae of spermatozoa. Gametogenesis continues until a new stage } 3 \mathrm{~A} \text { is reached prior to } \\
\text { further spawning. }\end{array}$ \\
\hline $3 \mathrm{D}$ & Spent & 1 & $\begin{array}{l}\text { After the final spawning, the follicles have begun to collapse and degenerate. A small number of } \\
\text { unspawned gametes are rapidly broken down by amoebocytes and the animal again enters the neuter } \\
\text { stage (resting). }\end{array}$ \\
\hline
\end{tabular}

Note: The numerical rank scoring scheme was adopted from Wilson and Seed (1974) and Buchanan (2001)

\section{RESULTS AND DISCUSSION}

\section{Sex ratio}

Sex determination of hard clam (Meretrix meretrix) based on external appearance is not possible. Thus, microscopic examination of the gonads was carried to determine the clam sex. Figure 2 shows the histological differences between female and male clams. Male clams were identified by the presence of spermatozoa and spermatids (Figure 2D), while the female clams were identified by the presence of the follicle wall and mature oocytes (Figure 2E). Stages implying the maturation of gonad are presented in Figure 3. Figure 4 summarizes the number of female and male individuals and the gonad developmental stages concerning sex and shell length. Histological analysis revealed that the natural stock of $M$. meretrix in Marudu Bay, although not significantly deviated from the $1: 1$ ratio $(\mathrm{c} 2=22.79, \mathrm{df}=2, \mathrm{P}>0.131)$, it was dominated by females at the ratio of 1.39 to 1.0 over the male (Table 2). Interestingly, younger specimens comprised of more females, but larger clams $(>7.00 \mathrm{~cm})$ were dominated by males. In terms of gonad maturation, more males were observed to have matured gonads than females (Figure 2). The number of ripe male and female specimens within the 5-6.99 $\mathrm{cm}$ shell length class was higher than that in the other classes (Figure 3). The natural stock of $M$. meretrix in Marudu Bay was dominated by females at a ratio of 1.39 to 1 male. Furthermore, these results are in line with Narasimham et al. (1988), which stated that the sex ratio of $M$. meretrix in Korampallam creek, India was also dominated by females at the ratio of 1.36:1 over males. However, it differs from a closely related species, $M$. lyrata which exhibits more males than females (Jayabal and Kalyani 1986; Hamli et al. 2015). According to (Hamli et al. 2015), most Meretrix species are dioecious, however, Chu and Kumar (2008) stated that $6 \%$ of $M$. lyrata are hermaphrodites. Regrettably, no hermaphroditism was observed in this study.

The numerous abiotic and biotic factors such as sex hormones (Wang and Croll 2004; Aji 2011), temperature, food availability, and pollution (Dridi et al. 2014; Breton et al. 2018) are known to influence sex ratio in bivalve species (Table 3). According to Wang and Croll (2004), sex hormones such as 17 $\beta$-estradiol, testosterone, progesterone, or dehydroepiandrosterone (DHEA) induced juvenile sea scallop to masculinity.

Temperature also affects the sex ratio in many oyster species. For example, Crassostrea virginica in North Carolina was discovered to become female-biased and protandric during warmer and cool-season, respectively (Coe 1936). Similarly, the Pacific oyster, Crassostrea gigas in France, was found to become female and male-biased during summer and winter respectively (Lango-Reynoso et al. 2006). However, Tropical Cortes oyster, C. corteziensis in north-western Mexico was observed to become male and female-biased in warm $\left(>18^{\circ} \mathrm{C}\right)$ and cool $\left(<9^{\circ} \mathrm{C}\right)$ seasons respectively (Chávez-Villalba et al. 2008).

Food has also been stated to influence the sex ratio of bivalve species. For example, Mytella charruana changed sex from female to male due to starvation (Stenyakina et al. 
2010). Also, C. gigas becomes female-biased as a result of sometimes caused by a high stocking density of a food starvation (Egami 1953). Food deprivation is population in an area (Ahmad et al. 2019).

Table 2. Chi-square analysis of the sex ratio with shell length, Meretrix meretrix in Marudu bay, Sabah, Malaysia

\begin{tabular}{|c|c|c|c|c|c|c|}
\hline \multirow{2}{*}{ Shell length $(\mathrm{cm})$} & \multicolumn{3}{|c|}{ Number } & \multirow{2}{*}{ Sex ratio (M: F, \%) } & \multirow{2}{*}{ Chi-square } & \multirow{2}{*}{$P$ value } \\
\hline & Total & Male & Female & & & \\
\hline $3.00-4.99$ & 38 & 14 & 24 & $1: 1.71(36.8: 63.2)$ & 2.632 & 0.105 \\
\hline $5.00-6.99$ & 38 & 16 & 22 & $1: 1.38(42.0: 58.0)$ & 0.947 & 0.330 \\
\hline$>7.00$ & 10 & 6 & 4 & $1: 0.67(60.0: 40.0)$ & 0.400 & 0.527 \\
\hline Total & 86 & 36 & 50 & $1: 1.39(42.0: 58.0)$ & 2.279 & 0.131 \\
\hline
\end{tabular}

Table 3. Factors which can affect sex ratio in bivalve species

\begin{tabular}{|c|c|c|c|c|}
\hline Bivalve species & Location & Factors affecting sex ratio & $\begin{array}{l}\text { Sex ratio (M: } \\
\text { F) }\end{array}$ & References \\
\hline Mya arenaria & $\begin{array}{l}\text { Baie du Moulin à Baude, } \\
\text { Tadoussac, QC, Canada }\end{array}$ & Tributylin contamination & $1.04: 1$ & Gagné et al. 2003 \\
\hline Mya arenaria & $\begin{array}{l}\text { Anse de Saint-Étienne, } \\
\text { Canada }\end{array}$ & Tributylin contamination & $1.73: 1$ & Gagné et al. 2003 \\
\hline Mya arenaria & $\begin{array}{l}\text { Baie-Sainte-Catherine, } \\
\text { QC, Canada }\end{array}$ & Tributylin contamination & $1.13: 1$ & Gagné et al. 2003 \\
\hline Gomphina veneriformis & South Korea & $\begin{array}{l}\text { Exposure of tributylin }(0.8 \mu \mathrm{g} / \mathrm{L}) \\
\text { for } 36 \text { weeks }\end{array}$ & $\begin{array}{l}\text { Initial; } 1: 1 \\
\text { Final; } 1.37: 1\end{array}$ & Park et al. 2015 \\
\hline Mya arenaria & $\begin{array}{l}\text { Bannow bay, southeast } \\
\text { coast Ireland }\end{array}$ & $\begin{array}{l}\text { Possible Climate change } \\
\text { Narrow temperature difference } \\
\text { between summer and winter } \\
(2.6 \mathrm{~cm}-11.6 \mathrm{~cm} \text { shell length })\end{array}$ & $1.15: 1$ & Cross et al. 2012 \\
\hline Tegillarca granosa & Jangsu Bay, Korea & Sequential hermaphrodites & $\begin{array}{l}\text { Initial; } 2.25: 1 \\
\text { Final; } 1.85: 1\end{array}$ & Lee et al. 2014 \\
\hline Crassostrea corteziensis & $\begin{array}{l}\text { Central Mexican Pacific } \\
\text { coast }\end{array}$ & $\begin{array}{l}\text { Hermaphroditism }(1.3 \%) \\
2-10 \mathrm{~cm} \text { in shell length }\end{array}$ & $0.32: 1$ & $\begin{array}{l}\text { Mena-Alcantar et } \\
\text { al. } 2017\end{array}$ \\
\hline Sinanodonta woodiana & $\begin{array}{l}\text { Cieply channel, north- } \\
\text { west Poland }\end{array}$ & $\begin{array}{l}\text { Hermaphroditism }(2.34 \%) \\
3-16 \mathrm{~cm} \text { shell length }\end{array}$ & $0.56: 1$ & $\begin{array}{l}\text { Labecka and } \\
\text { Domagala } 2018\end{array}$ \\
\hline Mytella charruana & $\begin{array}{l}\text { Southeastern, United } \\
\text { States }\end{array}$ & Food availability & $\begin{array}{l}\text { Initial; } 0: 1 \\
\text { Final; } 1.33: 1\end{array}$ & $\begin{array}{l}\text { Stenyakina et al. } \\
2010\end{array}$ \\
\hline Placopecten magellanicus & $\begin{array}{l}\text { Chester, Nova Scotia, } \\
\text { Canada }\end{array}$ & $\begin{array}{l}\text { Sex steroid: } \\
\text { Estradiol } \\
\text { Testosterone } \\
\text { Progesterone } \\
\text { Dehydroepiandrosterone }\end{array}$ & $\begin{array}{l}6.75: 1 \\
6: 0 \\
8.67: 1 \\
5.25: 1\end{array}$ & $\begin{array}{l}\text { Wang and Croll } \\
2004\end{array}$ \\
\hline Ostrea virginica & $\begin{array}{l}\text { Milford, Connecticut, } \\
\text { United States }\end{array}$ & $\begin{array}{l}\text { Breeding season: } \\
\text { Beginning sample (July) } \\
\text { Second sample (Aug) } \\
\text { Third sample (Sep) }\end{array}$ & $\begin{array}{l}17.72: 1 \\
7.06: 1 \\
4.38: 1\end{array}$ & Coe 1936 \\
\hline Crassostrea gigas & $\begin{array}{l}\text { Hatchery of Coast } \\
\text { Seafood Company, } \\
\text { Quilcene, Washington, } \\
\text { United States }\end{array}$ & $\begin{array}{l}\text { Environmentally determined: } \\
\text { One year old } \\
\text { Two years old } \\
\text { Three years old }\end{array}$ & $\begin{array}{l}1.7: 1 \\
0.82: 1 \\
0.33: 1\end{array}$ & Guo et al. 1998 \\
\hline Ostrea edulis & Sweden, Europe & Increase of temperature & $\begin{array}{l}>\text { proportion of } \\
\text { male individuals }\end{array}$ & Joyce et al. 2013 \\
\hline Tegillarca granosa & $\begin{array}{l}\text { Yueqing, Wenzhou, } \\
\text { China }\end{array}$ & $\begin{array}{l}\text { Exposure of major heavy metal }(\mathrm{Cu} \\
\geq 14.2 \mu \mathrm{g} / \mathrm{L}, \mathrm{Pb} \geq 86.0 \mu \mathrm{g} / \mathrm{L}, \mathrm{Cd} \\
\geq 110.0 \mu \mathrm{g} / \mathrm{L} \text { and } \mathrm{Zn} \geq 1.68 \mathrm{mg} / \mathrm{L}\end{array}$ & $\begin{array}{l}>\text { proportion of } \\
\text { male individual }\end{array}$ & Liu et al. 2014 \\
\hline Gomphina veneriformis & South Korea & $\begin{array}{l}\text { Exposure of } 0.8 \mu \mathrm{g} / \mathrm{L} \text { of Tributylin } \\
\text { for } 36 \text { weeks }\end{array}$ & $\begin{array}{l}\text { Initial; } 1: 1 \\
\text { Final; } 1.37: 1\end{array}$ & Park et al. 2015 \\
\hline Anadara indica & Semarang, Indonesia & $\begin{array}{l}\text { Sex reversal: } \\
<35 \mathrm{~mm} \text { shell length } \\
>35 \mathrm{~mm} \text { shell length }\end{array}$ & $\begin{array}{l}1: 1 \\
0.25: 1\end{array}$ & Afiati 2016 \\
\hline
\end{tabular}


A

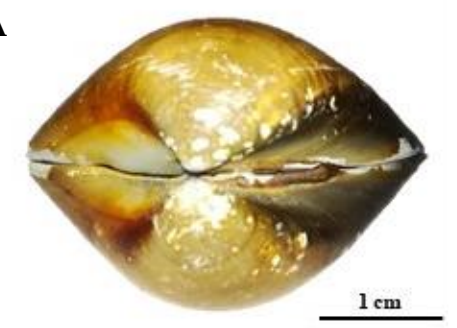

$\mathbf{B}$
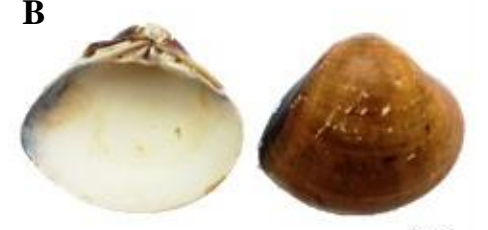

$\underline{1 \mathrm{~cm}}$

C

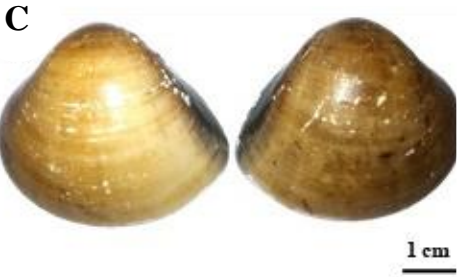

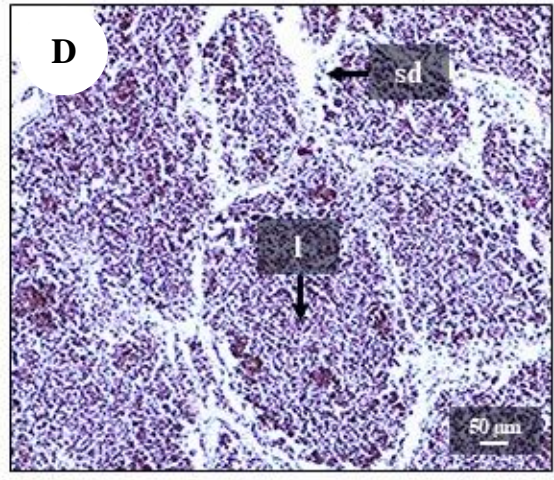

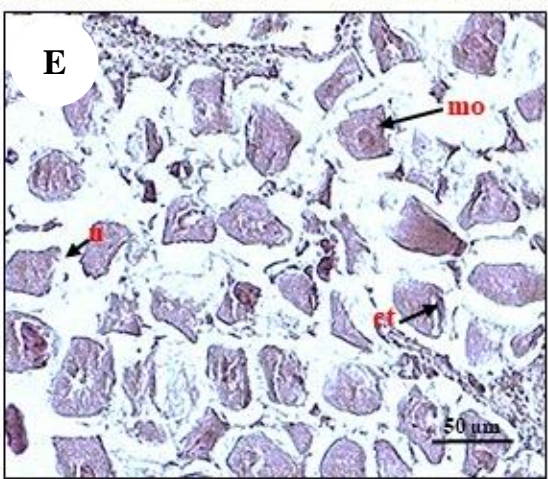

Figure 2. Sex ratio of Meretrix meretrix in Marudu Bay, Sabah, Malaysia. Note: A. Intact clam; B, C. Bisected clams; D. Gonad histology (male, 10x); E. Gonad histology (female, 10x); sd: spermatid; $l$ : lumen; mo: mature oocyte; $c t$ : connective tissuu; $n$ : nucleus

Organotin compounds (e.g., tributyltin), which are widely used as antifouling agents in the shipping industry, have been reported to induce masculinity in bivalves (e.g., Gomphina veneriformis and Mya arenaria) (Park et al. 2015). Furthermore, investigations were conducted on the effect of heavy metals on sex ratio, however, Liu et al. (2014) showed that the blood clam (Tegillarca granosa) skewed towards the male in the presence of a high concentration of copper $(\mathrm{Cu} 2+,>14.2 \mu \mathrm{g} / \mathrm{L})$, zink $(\mathrm{Zn} 2+$ $>1.68 \mathrm{mg} / \mathrm{L})$, lead $(\mathrm{Pb} 2+>86.0 \mu \mathrm{g} / \mathrm{L})$ and cadmium $(\mathrm{Cd} 2+$ $>110.0 \mu \mathrm{g} / \mathrm{L})$, respectively. Nevertheless, this study fails to establish the factors responsible for the female-biased sex ratio of the $M$. meretrix in Marudu Bay. Starvation and chemicals pollution do not influence the gander skewness of $M$. meretrix because the bay has high chlorophyll-a content (Sing and Ransangan 2019) and no excessive contamination from heavy metals (Denil et al. 2017). Whether or not the high temperature $\left(28^{\circ} \mathrm{C}-31^{\circ} \mathrm{C}\right)$ of the bay (Taib et al. 2015; Tan and Ransangan 2016) influences this observation was not analyzed in this study. Therefore, correct estimation of sex ratio is particularly important for artificial breeding in species like bivalves, which gander are difficult to identify morphologically, and also singlepair mating is often unproductive.

\section{Gonadal index}

The non-parametric analysis of gonad maturation showed a significant difference $(\mathrm{P}<0.05)$ among the males in the $3.00-4.99 \mathrm{~cm}$ and $5.00-6.99 \mathrm{~cm}$ shell length classes. While for females, it was noted no significant difference
( $\mathrm{P}>0.05)$ within the three shell length classes (3.00-4.99 $\mathrm{cm}, 5.00-6.99 \mathrm{~cm}$ and $>7.00 \mathrm{~cm}$ ). Clams with shell lengths between 5.00 and $6.99 \mathrm{~cm}$, irrespective of sex, appeared to have a higher gonadal index than the clams in the other two shell length classes (Figure 5). There was a significant difference $(\mathrm{P}<0.05)$ in terms of gonadal indexes between clams in the 5.00-6.99 cm and 3.00-4.99 cm shell lengths classes. However, no significant difference $(\mathrm{P}>0.05)$ of gonadal indexes was noted among big-sized clams $(>7.00$ $\mathrm{cm})$ compared to clams in the other shell length classes (Figure 6).

The gonadal index is defined as the ratio of the gonad to body size, which has been used to describe and analyze the reproductive cycle of marine species (Idris et al. 2017). Furthermore, the temporal variations in gonad size reflect the phases of the reproductive cycle (Erickson et al. 1985). Accumulation of nutrients in the gonad before gametogenesis and gametes production leads to gonadal growth, which increases the gonadal index. The release of gametes during spawning decreases the gonad size and index. However, in subsequent gametogenesis, the gonad size and index increase gradually (Walker et al. 2007). Results of the current study showed that bivalves require satisfactory environmental conditions (Hamli et al. 2019) and availability of foods (Dridi et al. 2014; Chilmawati 2016; Breton et al. 2018; Khafage et al. 2019) for gametogenesis and spawning to occur. The temperature was stated to influence the spawning activity of bivalves (Aji 2011; Sreedevi et al. 2014). Also, a previous study by Tomatala (2011) stated that the spawning of the pearl 
oyster (Pinctada maxima) was affected by the change in the temperature of the water, while Ouréns et al. (2012) highlighted the limitations of using the gonadal index to predict the reproductive cycle of marine species. However, there is a strong optimism on using the gonadal index to estimate the sexual maturation of tropical bivalves such as $M$. meretrix, where age determination is difficult.

Some temperate bivalves (e.g., Donax trunculus) become sexually matured with age (Gaspar et al. 1999), while tropical bivalves (e.g., Arca granosa) mature beyond a certain length (Maske and Muley 2015). This study observed that the gonadal index of $M$. meretrix with shell lengths between 5.00-6.99 $\mathrm{cm}$ was higher than other classes, though not significantly different from those larger clams $(>7.00 \mathrm{~cm})$. In contrast, the clams within the 3.00$4.99 \mathrm{~cm}$ shell length category have a significantly lower value of the gonadal index. In India, M. meretrix was reported to have attained first sexuality maturity at a shell length of 2.1-2.6 cm (Jayabal and Kalyani 1986). This is true in Marudu Bay because many clams were observed to have matured gonads at $3.0 \mathrm{~cm}$. However, the low number of small clams which have matured gonads is explained by the fact that there use more energy for growth rather than for gonad development (Zarnoch and Schreibman 2008), while larger clams $(>7.00 \mathrm{~cm})$ are considered old and require a lot of energy to maintain the declining metabolic rate.
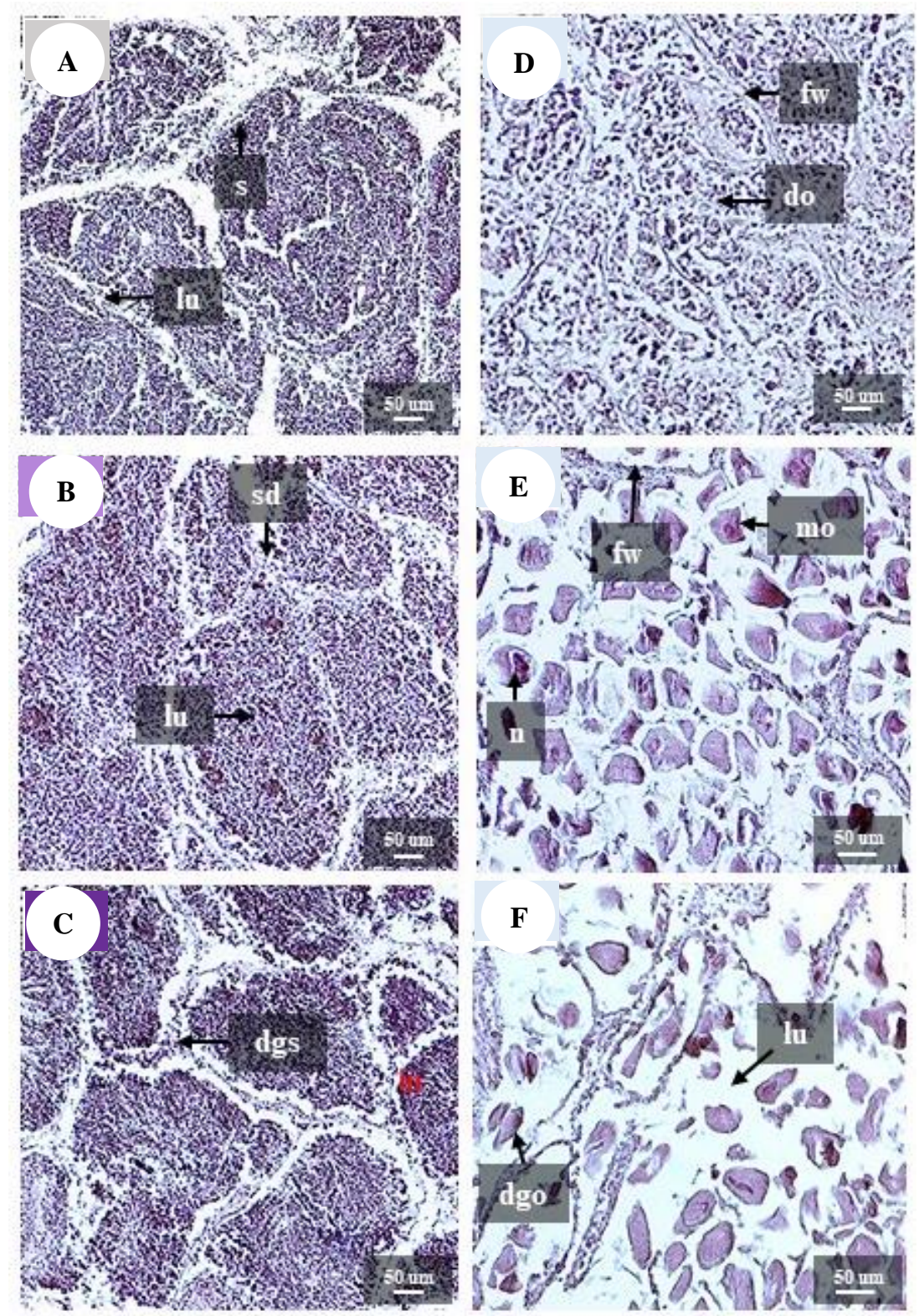

Figure 3. Maturation stages of the Meretrix meretrix. A, B, C. Immature, spawning and ripe males, respectively; D, E, F. Immature, spawning and ripe females, respectively; ct: connective tissue; sd: spermatid; sz: spermatozoa; l: lumen; dgs: degenerate spermatozoa/ spermatid/ spermatocyte; fw: follicle wall; do: developing oocyte; n: nucleus; mo: matured oocyte; dgo: degenerate oocyte 


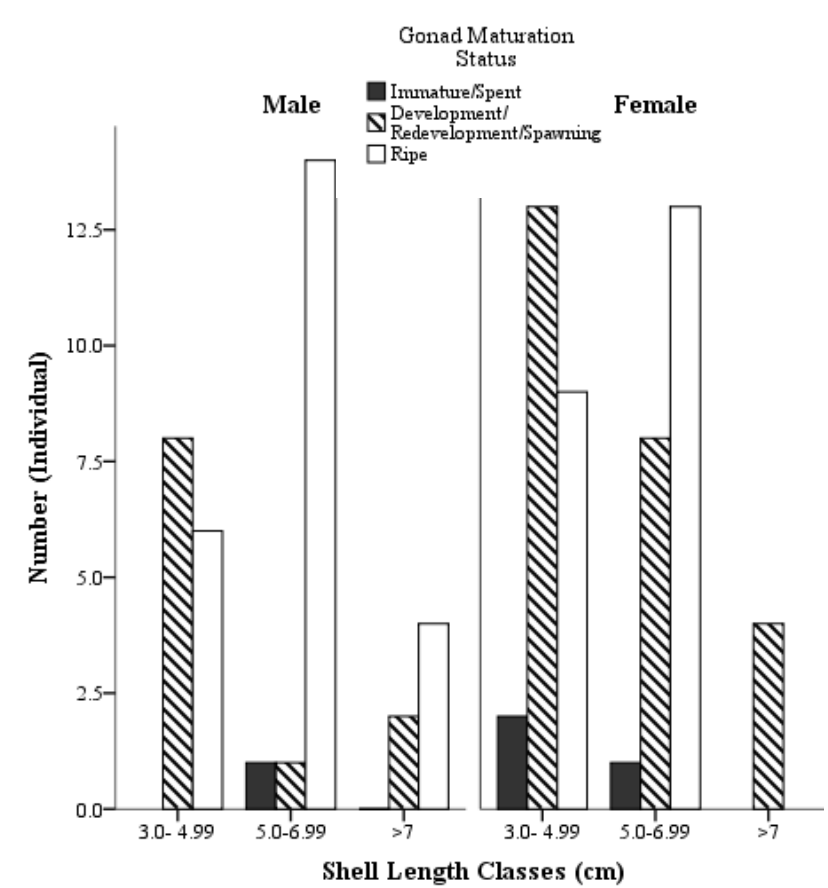

Figure 4. Gonad maturation stages of the Asiatic hard clam, Meretrix meretrix with respective to gander and shell length

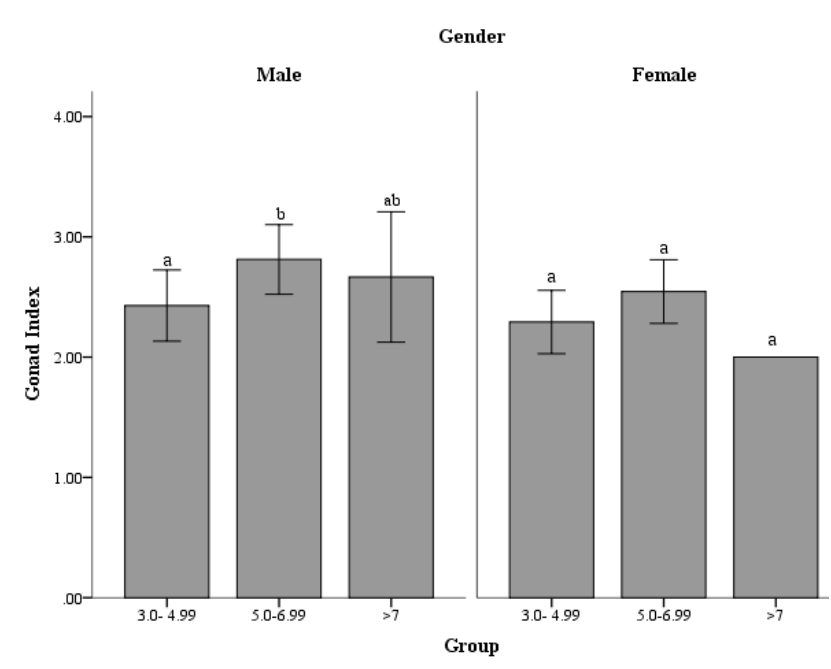

Figure 5. Gonadal index of Meretrix meretrix in Marudu Bay according to sex and shell length classes. Note: $a$ different from $b$; $a b$ not different from $a$ and $b$

\section{Condition index}

Statistical analysis showed there is no significant difference $(\mathrm{P}>0.05)$ in condition indexes among clams in all shell length classes (Figure 7).

The condition index increases when the gonad reaches the maturation phase, as more meats are produced or accumulated, and decreases when the gonad is in spent or resting phases (Hamli et al. 2017). According to Ismail (2012), the consummation of shellfish that were exposed to contamination such as mercury can result in lifethreatening conditions. Hence, the condition index is often used as an indicator of meat quality (Yenni and Nurjanah

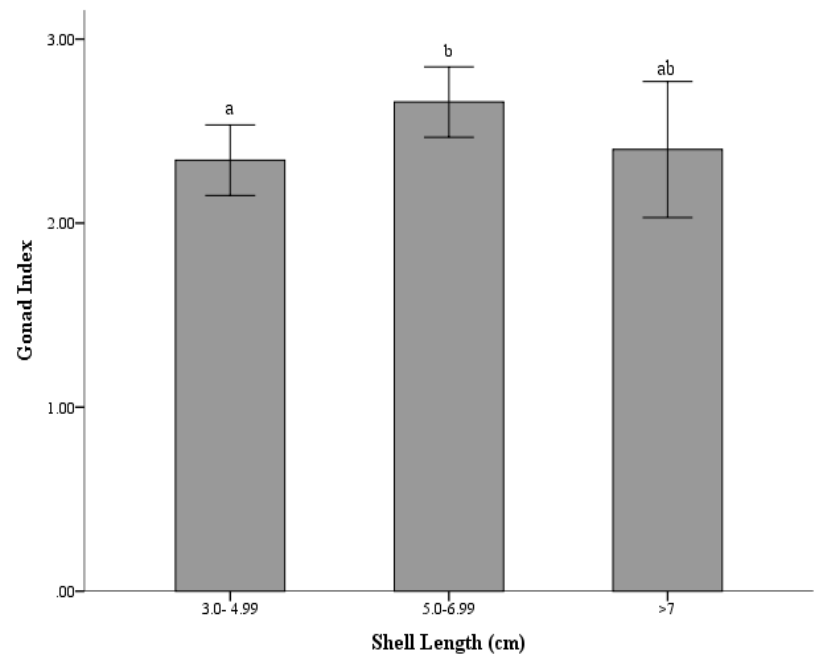

Figure 6. Gonadal index of Meretrix meretrix in Marudu according to shell length classes. Note: $a$ different from $b ; a b$ not different from $a$ and $b$

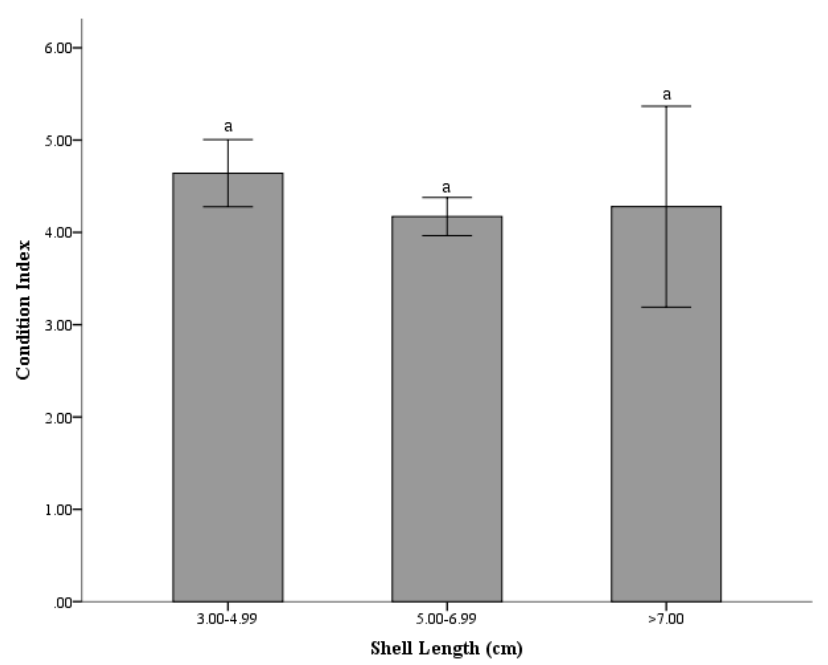

Figure 7. Condition index of Meretrix meretrix in Marudu Bay according to sex and shell length classes

2011; Teguh et al. 2016; Hassan et al. 2017; Arifin 2019) and performance of farmed bivalves (Filgueira et al. 2013). The gonad tissue represents $59 \%$ of the total soft tissues weight, thus contributing significantly to the total weight of the individual bivalve. However, differences in shell thickness, fecundity stages, feeding rates, and biomass density also influence the condition index of bivalves (Duinker et al. 2008).

Environmental conditions influence the condition index of clams (Tanyaros and Tongnunui 2011; Kasmini et al. 2018; Sinaga et al. 2018). Other previous studies also showed that temperature, salinity, and photoperiod affect the gonad development of bivalves (Zarnoch et al. 2008; 
Hamli et al. 2019). However, Joyce et al. (2013) reported that the gametogenesis and sex ratio of bivalve (e.g., Ostrea edulis) remain unaffected by temperature and photoperiod. Furthermore, gametogenesis requires high energy as a result of this it exhausts the energy storage and the condition index of animals (da Silva et al. 2009; Hassan et al. 2017; Hamli et al. 2019). The study showed that the energy expenditure in clams could be influenced by salinity, temperature and food availability (Miller et al. 2014). According to Lucas and Beninger (1985), bivalves with a high condition index could indicate that they do not experience high energy-consuming processes such as stresses due to poor environmental conditions, illnesses, gametogenesis, or spawning. Meanwhile, it was observed that clams within the class of 5.00-6.99 cm shell length had a lower condition index. This implies that the clams utilized more energies for biological efforts compared to those in lower $(3.00-4.99 \mathrm{~cm})$ and higher $(>7.0 \mathrm{~cm})$ classes of shell length, respectively.

In conclusion, the Asiatic hard clam (Meretrix meretrix) is an important species for artisanal shellfishery in Marudu Bay, Malaysia. Furthermore, the sex ratio of the clam in the bay was skewed toward the female population and exhibited a high condition index. It was also observed that clams with a shell length of 5.00-7.00 cm have a high gonad index, implying that sexual maturity has been fully attained. Therefore, this basic biological information be utilized in the future for a successful artificial breeding program for this clam.

\section{ACKNOWLEDGEMENTS}

This work was financially supported by the Fundamental Research Grant Scheme (FRGS0467-2017) from the Ministry of Higher Education, Malaysia.

\section{REFERENCES}

Acarli S, Lök A, Acarli D, Küçükdermenci A. 2018. Gamogenetic cycle, condition index and meat yield of the Noah's Ark shell (Arca noae Linnaeus, 1758) from Gerence Bay, Aegean Sea Turkey. Ege J Fish Aquat Sci 35 (2): 141-149. DOI: 10.12714/egejfas.2018.35.2.06.

Adebiyi FA. 2013. The sex ratio, gonadosomatic index, stages of gonadal development and fecundity of Sompat grunt, Pomadasys jubelini (Cuvier, 1830). Zool Soc Pak 45 (1): 41-46.

Admodisastro VA, Doinsing J, Duisan L, Madin J, Ransangan J. 2021. Population dynamics of Asiatic hard clam, Meretrix meretrix (Linnaeus,1758) in Marudu Bay, Malaysia: Implication for fishery resource management. J Fish Environ 45 (2): 92-105.

Afiati N. 2016. Tidal periodcity in microgrowth bands of blood clam Anadara indica (Bivalvia: Arcidae): A possible environmental sclerochronometer in the tropics. Jurnal Teknologi 78: 167-173. DOI: 10.11113/jt.v78.8200.

Aji LP. 2011. Review: Spawning induction in bivalve. Jurnal Penelitian Sains 14 (2): 33-36. DOI: 10.26554/jps.v14i2.115.

Ahmad Z, Junaidi M, Astriana, BH. 2019. Pengaruh kepadatan spat kerang mutiara (Pinctada maxima) dengan metode Longline terhadap pertumbuhan dan kelangsungan hidup. Jurnal Biologi Tropis 9 (2): 221-228. DOI: 10.29303/jbt.v19i2.1273. [Indonesia]

Arifin M. 2019. Komposisi Kimia Kerang Batik (Paphia Undulata) pada Lokasi yang Berbeda di Kecamatan Sedati Sidoarjo, Jawa Timur. [Doctoral Dissertation]. Airlangga University, Surabaya. [Indonesia]
Breton S, Capt C, Guerra D, Stewart D. 2018. Sex determining mechanisms in bivalves. In: Leonard JL (eds). Transitions Between Sexual Systems. Springer, Berlin.

Buchanan S. 2001. Measuring reproductivecondition in the Greenshell ${ }^{\mathrm{TM}}$ mussel Perna canaliculus. New Zealand J Mar Freshw Res 35 (5): 859-870.

Chávez-Villalba J, Hernández-Ibarra A, López-Tapia MR, MazónSuástegui JM. 2008. Prospective culture of the Cortez oyster Crassostrea corteziensis from northwestern Mexico: Growth, gametogenic activity, and condition index. J Shellfish Res 27 (4): 711-720. DOI: 10.2983/0730-8000(2008)27[711:PCOTCO]2.0.C $\mathrm{O} ; 2$.

Chávez-Villalba J, Soyez C, Huvet A, Gueguen Y, Lo C, Le Moullac G. 2011. Determination of gender in the pearl oyster Pinctada margaritifera. J Shellfish Res 30 (2): 231-240. DOI: 10.2983/035.030.0206.

Chilmawati D. 2016. The effect of different diet of phytoplankton cells on growth performance of copepod, Oithona sp. in semi-mass culture. Aquat Proc 7: 39-45. DOI: 10.1016/j.aqpro.2016.07.005.

Chu CT, Kumar MS. 2008. Clam (Meretrix lyrata) hatchery manual. Aquaculture Research Sub-Institute for North Centre (ARSINC) and South Australian Research and Development Institute (SARDI). Nghe An Province, Vietnam.

Coe WR. 1936. Environment and sex in the oviparous oyster Ostrea virginica. Biol Bull 71: 353-359. DOI: 10.2307/1537440.

da Silva PM, Fuentes J, Villalba A. 2009. Differences in gametogenic cycle among strains of the European flat oyster Ostrea edulis and relationship between gametogenesis and bonamiosis. Aquaculture 287 (3-4): 253-265. DOI: 10.1016/j.aquaculture.2008.10.055.

Cross ME, Lynch S, Whitaker A, O'Riordan RM, Culloty SC. 2012. The reproductive biology of the softshell clam, Mya arenaria, in Ireland, and the possible impacts of climate viarability. J Mar Biol 2012: 908163. DOI: 10.1155/2012/908163.

Denil DJ, Fui CF, Ransangan J. 2017. Season variations of heavy metals $(\mathrm{Cu}, \mathrm{Mn}, \mathrm{Ni}$ and $\mathrm{Zn})$ in farmed green mussel (Perna viridis) in Marudu Bay, Sabah, Malaysia. Intl J Aquat Sci 8 (1): 51-60. DOI: 10.4236/ojms.2017.74035.

Dridi S, Romdhane MS, Elcafsi MH. 2014. Gametogenic cycle of Crassostrea gigas in contrasting Mediterranean habitats: Marine (Gulf of Tunis) and continental (Bizert Lagoon) culture sites. J Biol Res Thessalon 21 (1): 13. DOI: 10.1186/2241-5793-21-13.

Duinker A, Håland L, Hovgaard P, Mortensen S. 2008. Gonad development and spawning in one and two year old mussels (Mytilus edulis) from Western Norway. J Mar Biol Assoc U K 88 (7): 14651473. DOI: 10.1017/S0025315408002130.

Egami N. 1953. Studies on sexuality in the Japanese oyster, Ostrea gigas. VII. Effects of gill removal on growth and sexuality. Annotationes Zoologicae Japonenses 26: 145-150.

El-Deeb RS, Razek FAA, Omar HA, Khafage AR, Abdul-Aziz KK. 2018. The gametogenic cycle and spawning of the mussel Brachidontes pharaonis (Fischer, 1876) (Bivalvia: Mytilidae) from Alexandria Coast, Egypt. Egypt J Aquat Res 44 (4): 353-359. DOI: 10.1016/j.ejar.2018.10.002.

Erickson DL, Hightower JE, Grossman GD. 1985. The relative gonadal index: An alternative index for quantification of reproductive condition. Comp Biochem Physiol Part A: Comp Physiol 81 (1): 117120. DOI: 10.1016/0300-9629(85)90276-2

Filgueira R, Comeau LA, Landry T, Grant J, Guyondet T, Mallet A. 2013. Bivalve condition index as an indicator of aquaculture intensity: A meta-analysis. Ecol Indic 25: 215-229. DOI:
D 10.1016/j.ecolind.2012.10. 001.

Gagné F, Blaise C, Pellerin J, Pelletier E, Douville M, Gauthier-Clerc S, Viglino L. 2003. Sex alteration in soft-shell clams (Mya arenaria) in an intertidal zone of the Saint Lawrence River (Quebec, Canada). Comp Biochem Physiol Part C: Toxicol Pharmacol 134 (2): 189-198. DOI: 10.1016/s1532-0456(02)00248-x.

Gaspar MB, Ferreira R, Monteiro CC. 1999. Growth and reproductive cycle of Donax trunculus L., (Mollusca: Bivalvia) off Faro, Southern Portugal. Fish Res 41 (3): 309-316. DOI: 10.1016/s01657836(99)00017-X.

Guo X, Hedgecock D, Hershberger WK, Cooper K, Jr SKA. 1998. Genetic determinants of protandric sex in the Pacific oyster, Crassostrea gigas Thunberg. Evolution 52 (2): 394-402. DOI: 10.1111/j.1558-5646.1998.tb01640.x. 
Hamli H, Idris MH, Hena MKA, Rajaee AH. 2019. Fisheries assessment, gametogenesis and culture practice of local bivalve: A review. Pertanika J Trop Agric Sci 42 (1): 103-124.

Hamli H, Idris MH, Rajaee A, Kamal AH. 2015. Reproductive cycle of hard clam, Meretrix lyrata Sowerby, 1851 (Bivalvia: Veneridae) from Sarawak, Malaysia. Trop Life Sci 26 (2): 59-72.

Hamli H, Idris MH, Rajaee AH, Kamal AHM, Hoque MN. 2017 Condition index of Meretrix lyrata (Sowerby 1851) and its relationship with water parameter in Sarawak. Sains Malaysiana 46 (4): 545-551. DOI: $10.17576 / \mathrm{jsm}-2017-4604-05$.

Hamdan D, Ngadnan N, Shah J, Tair R. 2019. Marudu Bay communitybased Geloina spp. aquaculture management: enhancing sustainable consumption, livelihood and food security. J Sustain Sci Manag 14 (5): $16-25$

Hassan MM, Qin JG, Li X. 2017. Gametogenesis, sex ratio and energy metabolism in Ostrea angasi: Implications for the reproductive strategy of spermcasting marine bivalves. J Molluscan Stud 84 (1): 38-45. DOI:10.1 093/mollus/eyx041.

Howard DW. 2004. Histological techniques for marine bivalve mollusks and crustaceans. NOAA Technical Memorandum NOS NCCOS 5: 218. http://hdl.handle.net/1834/30812.

Idris MH, Rahim AA, Hamli H, Nesarul MH, Kamal AHM. 2017. Determination of gonad development of mangrove clam Polymesoda expansa (Mousson 1849) by histological classification. J Fish Aquat Sci 12: 168-176. DOI: 10.3923/jfas.2017.168.176.

Ismail H. 2012. Hubungan manusia dan persekitaran fizikal: Suatu ulasan literatur kemerosotan kualiti udara dan sungai bandar. In: Rahman HA (eds). Manusia dan Kelestarian Persekitaran. Universiti Malaysia Terengganu, Terengganu, Malaysia. [Malaysia]

Jaya EN, Kartika R, Saleh C. 2017. Korelasi kadar ion logam Pb terhadap kadar protein pada Kerang Tahu (Meretrix meretrix) yang diambil di perairan Pantai Bunyu Kalimantan Utara. Prosiding Seminar Kimia, Mulawarman University, Kampus Gunung Kelua Samarinda, Kalimantan Timur, 13 Mei 2017. [Indonesian]

Jayabal R, Kalyani M. 1986. Reproductive cycles of some bivalves from Vellar estuary, east coast of India. Indian J Mar Sci 15: 59-60.

Joyce A, Holthuis TD, Charrier G, Lindegarth S. 2013. Experimental effects of temperature and photoperiod on synchrony of gametogenesis and sex ratio in the European oyster Ostrea edulis (Linnaeus). J Shellfish Res 32 (2): 447-458. DOI 10.2983/035.032.0225.

Kasmini L, Barus TA, Sarong MA, Mulya MB. 2018. Hubungan panjang berat dan faktor kondisi tiram (Crassostrea gigas) di Kawasan Estuari Tibang dan Ulee Lheue, Kota Banda Aceh. DEPIK Jurnal Ilmu-Ilmu $\begin{array}{llll}\text { Perairan Pesisir Perikanan } 7 & \text { (1): 60-68. DOI }\end{array}$ 10.13170/depik.7.1.9594

Khafage AR, Razek FAA, Taha SM, Omar HA, Attallah MA, El-Deeb RS. 2019. Gonadal cycle and spawning of Date mussel Lithophaga lithophaga (L.) (Bivalvia: Mytilidae) in Egyptian water. Egypt J Aquat Res 45 (3): 293-299. DOI: 10.1016/j.ejar.2019.04.001.

King P, McGrath D, Gosling E.1989. Reproduction and settlement of Mytilus edulis on an exposed rocky shore in Galway Bay, West Coast of Ireland. J Mar Biol Assoc U K 69 (2): 355-365. DOI: $10.1017 /$ S0025315400029465.

Labecka AM, Domagala J. 2018. Continous reproduction of Sinanodonta woodiana (Lea, 1824) females: An invasive mussel species in a female-biased population. Hyrobiologia 810: 57-76. DOI: $10.1007 / \mathrm{s} 10750-016-2835-2$

Lango-Reynoso F, Chavez-Villaba J, Le Pennec M. 2006. Reproductive patterns of the Pacific oyster Crassostrea gigas in France. Inverteb Reprod Develop 49: 41-50. DOI: 10.1080/07924259.2006.9652192.

Lagade V, Taware S, Muley D. 2013. Commercial harvesting and economy of edible clam species in Bhatye estuary, Ratnagiri (MS), India. Indian J Geo Mar Sci 42 (5): 665-669.

Lee JS, Park JJ, Shin YK, Kim H, Jeon MA. 2014. Sex change and sequential hermaphroditism in Tegillarca granosa (Bivalvia: Arcidae). Invertebr Reprod Develop 58 (4): 314-318. DOI: 10.1080/07924259.2014.949014

Lucas A, Beninger PG. 1985. The use of physiological condition indices in marine bivalve aquaculture. Aquaculture 44 (3): 187-200. DOI 10.1016/0044-8486(85)90243-1.

Liu GX, Shu MA, Chai XL, Shao YQ, Wu HX, Sun CS, Yang SB. 2014. Effect of chronic sublethal exposure of major heavy metals on filtration rate, sex ratio and gonadal development of a bivalve species. Bull Environ Contam Toxicol 92: 71-74. DOI 10.1007/s00128-013$1138-9$.
Martínez P, Viñas AM, Sánchez L, Díaz N, Ribas L, Piferrer F. 2014 Genetic architecture of sex determination in fish: Applications to sex ratio control in aquaculture. Frontiers Genet 5: 340. DOI: 10.3389/fgene.2014.00340.

Maske S, Muley D. 2015. Histological study on reproductive cycle of estuarine clam Arca granosa from Bhatye Estuary, Ratnagiri (MS) India. Biosci Discov 6 (1-1): 37-42.

Mena-Alcantar M, Zavala-Leal OI, Romero-Banuelos CA, Ruiz-Velazco JMJ, Nieto-Navarro JT, Palacios-Salgado D, Pacheco-Vega JM. 2017. Reproductive of cortez oyster, Crassostrea corteziensis (Hertlein, 1951) in a growing area in the central Mexican Pacific coast. Lat Am J Aquat Res 45 (2): 485-490. DOI: 10.3856/vol45-issue2-fulltext-23.

Miller NA, Chen X, Stillman JH. 2014. Metabolic physiology of the invasive clam, Potamocorbula amurensis: The interactive role of temperature, salinity, and food availability. Plos One 9 (3): e91064. DOI: 10.1371 / journal.pone.0091064.

Mojiol AR, Kodoh J, Wahab R, Majuki M. 2016. Contribution of nonwood forest product to the local community living near mangrove forest in Kudat, Sabah. J Trop Resour Sustain Sci 4 (1): 38-41. DOI: 10.47253 /jtrss.v4i1.578

Narasimham KA, Muthiah P, Sundararajan D, Vaithinathan N. 1988. Biology of the great clam, Meretrix meretrix in the Korampallam creek, Tuticorin. Indian J Fish 35 (4): 288-293.

Oliveira J, Castilho F, Cunha Â, Pereira MJ. 2013. Bivalve harvesting and production in Portugal: An overview. J Shellfish Res 32 (3): 911-924. DOI: $10.2983 / 035.032 .0334$

Ouréns R, Freire J, Fernández L. 2012. Definition of a new unbiased gonad index for aquatic invertebrates and fish: Its application to the sea urchin Paracentrotus lividus. Aquat Biol 17: 145-152. DOI: $10.3354 / \mathrm{ab} 00476$.

Park JJ, Shin YK, Hung SS, Romano N, Cheon YP, Kim JW. 2015. Reproductive impairment and intersexuality in Gomphina veneriformis (Bivalvia: Veneridae) by the tributyltin compound. Anim Cells Syst 19: 61-68. DOI: 10.1080/19768354.2014.995225.

Rohmah A, Muhsoni FF. 2020. Dinamika populasi Kerang Tahu (Meretrix meretrix) di perairan Bancaran Bangkalan Madura. Juvenil: Jurnal Ilmiah Kelautan dan Perikanan 1 (3): 331-338. DOI: 10.21107/juvenil.v1i3.8561.

Sawant PP. 2012. Morphology and biology of Meretrix meretrix (Linnaeus, 1758) along Ratnagiri coast, Maharashtra. [Thesis]. College of Fisheries, Shirgaon, Ratnagiri, Dapoli, India.

Sing OF, Ransangan J. 2019. Effect of physicochemical parameters and phytoplankton composition on growth performance of green mussel (Perna viridis) in Ambong Bay and Marudu Bay, Sabah, Malaysia. J Fish Environ 43 (1): 50-68.

Sinaga S, Febri SP, Haser TF, Azmi F. 2018. Hubungan panjang dan berat serta faktor kondisi Kerang Bulu, Anadara antiquata di Ujung Perling, Kota Langsa Aceh. Jurnal Ilmiah Samudra Akuatika 2 (2): 30-34. [Indonesian]

Sreedevi PR, Uthayakumar V, Jayakumar R, Ramasubramanian V. 2014. Influence of rearing water temperature on induced gonadal development and spawning behaviour of tropical green mussel, Perna viridis. Asian Pac J Reprod 3 (3): 204-209. DOI: 10.1016/S23050500(14)60027-0.

Stenyakina A, Walters LJ, Hoffman EA, Calestani C. 2010. Food availability and sex reversal in Mytella charruana, an introduced bivalve in the southeastern United States. Mol Reprod Develop 77: 222-230. DOI: $10.1002 / \mathrm{mrd} .21132$.

Sundaram S, Deshmukh VD. 2011. Commercially exploited edible bivalves off Mumbai. Fishing Chimes 31 (5): 23-24.

Tan KS, Ong FS, Denil DJ, Ransangan J. 2017. Distribution and fishing pressure of hard clam, Meretrix meretrix in Marudu Bay, Sabah. Intl Ocean Oceanogr 11 (2): 265-276.

Tan KS, Ransangan J. 2016. Effects of environmental conditions and nutrients on the occurrence and distribution of potentially harmful phytoplankton in mesotrophic water. Sains Malaysiana 45 (6): 865877.

Tan KS, Ransangan J. 2019. Dredging-induced shell damages to hard clam (Meretrix meretrix): A Malaysian case study. Aquat Living Resour 32 (1): 7. DOI: $10.1051 / \mathrm{alr} / 2018025$

Tanyaros S, Tongnunui P. 2011. Influence of environmental variables on the abundance of estuarine clam Meretrix casta (Chemnitz, 1782) in Trang Province, Southern Thailand. Songklanakarin J Sci Technol 33 (1): $107-115$.

Taib AM, Madin J, Ransangan J. 2016. Density, recruitment and growth performance of Asian green mussel (Perna viridis) in Marudu bay, 
Northeast Malaysian Borneo, three years after a mass mortality event. Songklanakarin J Sci Technol 38 (6): 631-639.

Teguh TW, Anggoro S, Widowati I. 2016. Bioekologi Kerang Simping (Amusium pleuronectes) di Perairan Kabupaten Brebes. Prosiding Seminar Nasional Tahunan ke-V Hasil-Hasil Penelitian Perikanan dan Kelautan. Fakultas Perikanan dan Ilmu Kelautan Universitas Diponegoro, Semarang, Juni 2016. [Indonesian]

Tomatala P. 2011. Pengaruh suhu terhadap pemijahan kerang mutiara Pinctada maxima (Jameson). Jurnal Perikanan Kelautan Tropis 7 (1) 36-38. DOI: $10.35800 /$ jpkt.7.1.2011.13.

Walker S, Ryen C, McCormick M. 2007. Rapid larval growth predisposes sex change and sexual dimorphism in a protogynous hermaphrodite, Parapercis snyderi Jordan \& Starks 1905. J Fish Biol 71: 1347-1357. DOI: $10.1111 / j .1095-8649.2007 .01595 . x$.

Walne PR. 1976. Experiments on the culture in the sea of the butterfish Venerupis decussata L. Aquaculture 8 (4): 371-381. DOI: 10.1016/0044-8486(76)90119-8.

Wang C, Croll RP. 2004. Effects of sex steroids on gonadal development and gender determination in the sea scallop, Placopecten magellanicus. Aquaculture 238: 483-498. DOI: 10.1016/j.aquaculture.2004.05.024.
Wilson JH, Seed R. 1974. Reproduction in Mytilus edulis L. (Mollusca: Bivalvia) in Carlingford Lough, Northern Ireland. Irish Fish Invest (Ser B) 15: 3-30.

Yenni NT, Nurjanah LF. 2011. Kandungan mineral, proksimat dan penanganan kerang pokea (Batissa violacea celebensis Marten 1897) dari Sungai Pohara Sulawesi Tenggara Pros. Pertemuan Ilmiah dan Seminar Nasional. Sam Ratulangi University, Manado. [Indonesian]

Yurimoto T, Mori Y, Ito S, Maeno Y. 2008. Reproductive cycle of the subcrenated ark shell Scapharca kogoshimensis (Tokunaga, 1906) in Ariake Bay, Japan. J Shellfish Res 27 (5): 1101-1108. DOI: 10.2983/0730-8000-27.5.1101.

Zakaria M, Rajpar MN. 2015. Assessing the fauna diversity of Marudu Bay mangrove forest, Sabah, Malaysia, for future conservation. Diversity 7 (2): 137-148. DOI: 10.3390/d7020137.

Zarnoch CB, Schreibman MP. 2008. Influence of temperature and food availability on the biochemical composition and mortality of juvenile Mercenaria mercenaria (L.) during the over-winter period. Aquaculture 274: 281-291. DOI: 10.1016/j.aquaculture.2007.12.001. 